\title{
PENERAPAN DIGITAL MARKETING SEBAGAI STRATEGI KOMUNIKASI PEMASARAN USAHA KECIL DAN MENENGAH WARGA DEPOK JAYA
}

\author{
Iskandar Zulkarnain, Tabah Heri Setiawan, Budi Syamtoro, Muhamad Nurhamdi, \\ Irma Sari Octaviani \\ Program Studi Manajemen \\ Universitas Pamulang \\ iszul0579@gmail.com
}

\begin{abstract}
This community service activity aims to transfer the knowledge and techniques of making simple financial statements to the Jama'at Al Awwal Mosque in Jakarta so that they can implement and practice Digital Marketing as a marketing communication strategy in Depok Jaya subdistrict. The method used in the form of delivery of material and practice / application of digital marketing such as the use of Facebook, Instagram, Gojek, Grab and so forth. The results of the activities showed that before the PKM implementation of the Al Awwal Jamaat Mosque the depok jaya lacked mastery of the application as a marketing strategy for the products sold, but after the implementation of the activity it was known that the Al Awwal Mosque of the depok jaya mosque was quite mastered and could make the appearance and use of digital marketing. PKM activities indirectly have a very positive role in increasing participant knowledge and participant skills in making simple financial statements. The method of activity used is in collaboration with the Head of the Mosque Management at Al Awwal Mosque, Jalan Mawar Raya Depok Jaya and looking for problems in that place so as to provide the right solution in motivating as a businessman in Depok, West Java, especially the Jamaat Al Awwal Mosque, Depok Jaya. After the analysis, we provide training in material and practice forms in developing the use of digital marketing applications as a means to market the products to representatives of the Head of the Neighborhood Association in the Jamaat Masjid Al Awwal, Depok Jaya.
\end{abstract}

Keywords: marketing applications, digital marketing, marketing strategies

\begin{abstract}
Abstrak
Kegiatan pegabdian kepada masyarakat ini bertujuan untuk mentransfer pengetahuan dan teknik pembuatan laporan keuangan sederhana pada Jamaah Mesjid Al Awwal depok jaya agar dapat menerapkan dan
\end{abstract}


mempraktikan digital marketing sebagai strategi komunikasi pemasaran di Kelurahan Depok Jaya. Adapun metode yang dilakukan berupa penyampian materi dan praktik/penerapan digital marketing seperti penggunaan Facebook, Instagram, Gojek, Grab, dan aplikasi lain sebagainya. Hasil kegiatan menunjukkan bahwa sebelum pelaksanaan PKM Jamaah Mesjid Al Awwal depok jaya kurang menguasai aplikasi sebagai strategi pemasaran produk barang yang dijual, namun setelah pelaksaan kegiatan diketahui Jamaah Mesjid Al Awwal depok jaya cukup menguasai dan dapat membuat tampilan dan kegunaan digital marketing. Kegiatan PKM secara tidak langsung sangat berperan positif dalam meningkatkan pengetahuan peserta dan keterampilan peserta dalam pembuatan laporan keuangan sederhana. Metode kegiatan yang digunakan adalah bekerjasama dengan Kepala Pengurus Mesjid di Masjid Al Awwal Jalan Mawar Raya Depok Jaya dan mencari pemasalahan yang ada di tempat tersebut sehingga dapat memberikan solusi yang tepat dalam memotivasi sebagai pebisnis di Depok Jawa Barat khususnya Jamaah Mesjid Al Awwal Depok Jaya. Setelah di analisis maka kami memberikan pelatihan dalam bentuk materi dan praktek dala mengembangkan penggunanaan aplikasi digital marketing sebagai sarana untuk memasarkan produk kepada para perwakilan Ketua Rukun Warga di Jamaah Mesjid Al Awwal Depok Jaya.

Kata Kunci: aplikasi pemasaran, digital marketing, strategi pemasaran.

\section{A. PENDAHULUAN}

Usaha Kecil dan Menengah (UKM) di Indonesia bisa dibilang bertumbuh sangat pesat. Di pertengahan 2016, jumlah UMKM di Indonesia telah mencapai 57,9 juta.1 Menurut Deputi Bidang Produksi dan Pemasaran Kementrian Koperasi dan Usaha Kecil Menengah, I Wayan Dipta jumlah tersebut sudah sangat potensial untuk bisa go international. Pemerintah sendiri sedang mendorong penuh agar para UKM tersebut bisa go international. Salah satu caranya dengan mengajarkan menggunakan internet yang menjadi salah satu cara memudahkan pemasaran hingga ke pasar internasional. Apalagi era bonus demografi yang segera Indonesia hadapi di tahun 2020-2035, akan menimbulkan dampak persaingan yang ketat. Jika, tidak ada dukungan pemangku kebijakan, UKM akan kalah bersaing dengan pesaing dari luar.

Sejalan dengan Siaran Pers No. 216/HM/KOMINFO/11/2017 oleh Kementrian Komunikasi dan Informatika (KOMINFO) mengenai Go Digital! Gerakan Nasional UKM Go Online tanggal 7 November 2017. Gerakan ini mendukung visi ekonomi Indonesia tahun 2020 ialah menjadi "The Digital Energy of Asia" dengan target pertumbuhan transaksi eCommerce sebesar USD 130 Miliar. Dalam mengejar visi ini, menghadapi dua tantangan utama yang harus diselesaikan secara seimbang dan serentak yaitu globalisasi dan sistem ekonomi yang adil dan produktif, yang berpihak pada rakyat serta terjaminnya sistem insentif 
ekonomi yang adil dan mandiri. Era digital memang tidak mungkin untuk dihindari. Pakar pemasaran Yuswohadi mengungkapkan bahwa jika ingin bertahan, maka pelaku UMKM harus mampu memaksimalkan manfaat perkembangan digital.

Dengan pesatnya perkembangan teknologi, dunia digital dan internet tentu juga berimbas pada dunia pemasaran. Tren pemasaran di dunia beralih dari yang semula konvensional (offline) menjadi digital (online). Digital marketing ini lebih prospektif karena memungkinkan para calon pelanggan potensial untuk memperoleh segala macam informasi mengenai produk dan bertransaksi melalui internet.

Menurut data yang dilansir oleh We are Social, sebuah agensi digital marketing di Amerika, memaparkan bahwa terhitung sampai Januari 2017, sebanyak $48 \%$ pengguna internet di Indonesia melakukan pencarian barang atau jasa secara online, $46 \%$ pengguna

mengunjungi toko online, $41 \%$ pengguna transaksi produk atau melayani jasa online, 34\% pengguna melakukan transaksi online via computer atau laptop, dan 33\% pengguna melakukan transaksi online melalui perangkat mobile seperti smartphone. Hal ini menyiratkan bahwa potensi belanja online sudah cukup berkembang di Indonesia yang harus diimbangi dengan pemasaran secara digital pula oleh para pelaku usaha.Platform yang sering digunakan dalam digital marketing adalah media sosial atau jejaring sosial. Disebutkan juga data dari We are Social bahwa platform media sosial yang paling banyak digunakan di Indonesia per Januari 2017 adalah Youtube (49\%) dan Facebook (48\%). Posisi selanjutnya ditempati oleh Instagram (39\%), Twitter (38\%), Whatsapp (38\%), dan Google+ (36\%). Sisanya ditempat secara berurutan oleh FB messenger, Line, Linkedin, BBM, Pinterest, dan Wechat.

Melalui survei Asosiasi Penyelenggara Jasa Internet Indonesia (APJII), pertumbuhan penetrasi internet di Indonesia telah mencapai angka 54,68 \% di sepanjang tahun 2017. Dari total 262 juta penduduk Indonesia, 143,26 juta jiwa diantaranya diperkirakan telah menggunakan internet, baik dari komputer desktop, perangkat mobile, atau dari fasilitas lainnya. Tentu promosi yang memanfaatkan internet semakin menjadi pilihan yang tidak dapat ditolak lagi melihat dari pertumbuhan jumlah penetrasi internet di Indonesia sendiri. Dengan memanfaatkan internet sebagai media komunikasi dalam memasarkan produk ataupun jasa, diharapkan mampu menjangkau pasar yang lebih luas sehingga semakin banyak yang mengetahui dan dapat membeli produk atau jasa yang ditawarkan. Apalagi dengan gaya hidup masyarakat di Indonesia yang tidak bisa lepas dari gawai, generasi netizen-pun juga memanfaatkan hal tersebut, tentu ini merupakan peluang yang besar.

Hal tersebut semakin menjadikan peneliti tertarik untuk melanjutkan riset berkaitan dengan penerapan digital marketing sebagai strategi komunikasi pemasaran. Sebelumnya, ada salah satu riset terdahulu pada tahun 2013, penelitiannya berjudul "Media Online (Website, Twitter, Facebook) sebagai Strategi Komunikasi Pemasaran Dablongan Clothing dalam Meningkatkan Penjualan". Beragam penelitian mengenai media online dan strategi komunikasi pemasaran khususnya yang terkait dengan produk UKM sudah ada beberapa yang meneliti. Namun untuk subyek penelitian yang berbasis pelaku usaha dalam sebuah komunitas atau kumpulan para pelaku usaha di suatu daerah seperti di Kelurahan Depok Jaya menurut peneliti masih jarang dilakukan. 


\section{B. METODE PELAKSANAAN KEGIATAN}

Kegiatan pengabdian kepada masyarakat dilaksanakan di Masjid Al Awwal Jalan Mawar Raya, Kelurahan Depok Jaya, Kecamatan Pancoran Mas, Kota Depok, Provinsi Jawa Barat. Kegiatan ini dilaksanakan dari tanggal 20 s.d 22 Oktober 2019. Sasaran program ini yaitu pelaku UMKM warga Kelurahan Depok jaya khususnya Jamaah Masjid Al Awwal dan terbuka umum untuk semua pelaku UMKM disekitar wilayah Kelurahan Depok Jaya.

Untuk metode pelaksanaan pengabdian berupa penyuluhan dan pelatihan. Sedangkan pasca kegiatan peserta dipersilahkan mengajukan permohonan pendampingan bila ada yang masih kesulitan dalam menerapkan digital marketing. Untuk rincian kegiatan yang telah dilaksanakan dapat dilihat pada Tabel 1 .

Tabel 1. Uraian Materi Program Pengabdian Kepada Masyarakat

\begin{tabular}{|c|c|c|c|}
\hline No & Jenis Materi Pembekalan & $\begin{array}{c}\text { Metode } \\
\text { Pelaksanaan }\end{array}$ & Tujuan Pemberian Materi \\
\hline 1 & $\begin{array}{l}\text { Mengenal berbagai aplikasi } \\
\text { untuk digital marketing }\end{array}$ & Penyuluhan & $\begin{array}{l}\text { Memberikan pengetahuan tentang } \\
\text { berbagai aplikasi/ perangkat lunak } \\
\text { yang dapat digunakan dalam } \\
\text { proses pemasaran produk secara } \\
\text { digital. }\end{array}$ \\
\hline 2 & Teknik Optimasi Aplikasi & Pelatihan & $\begin{array}{l}\text { Meningkatkan keterampilan } \\
\text { pelaku UMKM dalam } \\
\text { mengoptimalkan aplikasi sehingga } \\
\text { trafik pemasaran via digital dapat } \\
\text { meningkat khususnya produk yang } \\
\text { tahan lama melalui optimalisasi } \\
\text { media sosial. }\end{array}$ \\
\hline 3 & Teknik Fotografi & Pelatihan & $\begin{array}{l}\text { Meningkatkan keterampilan } \\
\text { pelaku UMKM } \\
\text { menghasilkan foto produk supaya } \\
\text { menarik dan memiliki kesan } \\
\text { professional }\end{array}$ \\
\hline
\end{tabular}

Untuk mengevaluasi keberhasilan program pemanfaatan digital marketing tersebut dilakukan dengan dua cara sebagai berikut:

1. Evaluasi demonstrasi, dengan menilai keikutsertaan peserta dalam praktik kegiatan yang dilakukan. Program dianggap berhasil jika minimal 80 persen peserta terlibat dalam dan mampu mengadopsi teknik pemasaran via digital marketing.

2. Evaluasi dampak kegiatan dilakukan dengan melihat banyaknya peserta yang telah mempraktikkan digital marketing untuk memasarkan produk UMKM, dengan indikator adanya peningkatan konten pemasaran pada aplikasi dan meningkatnya trafik penjualan produk. 


\section{HASIL DAN PEMBAHASAN}

\section{Pemasaran Media Sosial (Social Media Marketing)}

Media sosial (Social Media) adalah media yang didesain untuk memudahkan interaksi sosial yang bersifat interaktif dan dua arah. Media sosial berbasis pada teknologi internet yang mengubah pola penyebaran informasi yang sebelumnya bersifat satu ke banyak audiens, banyak audiens ke banyak audiens. Media sosial menurut Kaplan and Haenlein merupakan sekelompok aplikasi yang berbasiskan pada internet dan dibangun berdasarkan kerangka pikiran ideologi dan teknologi dari platform Web 2.0, medium ini dapat menghubungkan individu dengan individu untuk sharing dan berkumpul secara online. Web 2.0 merupakan suatu platform dasar terbentuknya media sosial, platform ini menyediakan kemudahan bagi penggunanya untuk berkolaborasi secara online dan berbagi (sharing).

Media sosial seperti Facebook, Twitter, Youtube, Instagram, saat ini digunakan untuk menyebarluaskan informasi secara cepat, viral, dan menyebar kepada pengguna internet dalam jumlah yang besar. Menurut Dan Zarella, media sosial adalah sebuah paradigma baru dalam konteks industri pemasaran yang paling baik dijelaskan dalam konteks paradigma industri media tradisional. Media tradisional, semisal televisi, surat kabar, radio, dan majalah adalah teknologi monolog dan statis.

\section{Karakteristik Media Sosial,}

Dalam jurnal User Participation of Social Media, disebutkan lima karakteristik utama dalam media sosial:

1. Participation, suatu tindakan yang berorientasikan pada keterlibatan pengguna dalam menggunakan media sosial, dapat berupa frekuensi kunjungan dan lama penggunaan.

2. Opennes, kondisi saat media sosial tidak memiliki hambatan untuk mengakses informasi dan membagikan konten tertentu.

3. Conversation, percakapan yang terjadi di media sosial dapat menyebar secara cepat karena kemudahan akses yang terhubung dengan internet.

4. Community, media sosial menawarkan sebuah mekanisme bagi individu atau organisasi untuk membentuk komunitas yang memiliki kesamaan minat.

5. Connectedness, informasi dalam media sosial berkarakteristik viral, kondisi ini memberikan kemudahan bagi penggunanya untuk terhubung satu dengan yang lain.

Teknologi digital akan membantu manajemen perusahaan sehingga aktivitas pemasaran akan mengarah pada dua hal, yakni peningkatan pendapatan dan pengurangan biaya yang akhirnya secara efektif meningkatkan nilai perusahaan. Seperti pendapat Zarella yang dikutip dari jurnal Iman K dkk, bahwa media sosial dalam pemasaran dapat menekan biaya dan memberikan dampak yang besar atau istilahnya "low budget, more effect" dan dari penelitian yang dilakukan oleh Neti yang dikutip dari jurnal yang sama bahwa peran media sosial dalam pemasaran antara lain:

1. Media sosial dapat memberikan identitas mengenai produk yang ditawarkan.

2. Berperan sebagai penelitian pemasaran dalam usaha mencari informasi mengenai kebutuhan konsumen.

3. Media sosial dapat dijadikan sebagai penghubung komunikasi antara pemasar dengan konsumen, hal ini bertujuan untuk mempertahankan hubungan dengan konsumen. 
4. Media sosial mendekatkan perusahaan dengan konsumen. Konsumen dapat mereduksi waktu yang mungkin digunakan hanya untuk melihat produk secara langsung, media sosial berfungsi untuk menampilkan produk setiap waktu.

5. Media sosial ditujukan untuk membangun customer engagement (kualitas interaksi).

\section{Definisi Pemasaran Media Sosial (Social Media Marketing)}

Pertumbuhan popularitas media sosial adalah tren utama dalam bisnis digital. Dalam situs jejaring sosial tertentu seperti Facebook, Google+, Twitter, Instagram dan untuk pengguna bisnis-ke-bisnis (B2B), LinkedIn dan umpan RSS. Beberapa situs media sosial bersifat independen dari jejaring sosial, termasuk blog yang dibuat oleh banyak individu dan bisnis. Pemasaran media sosial juga mencakup media seperti video online dan aplikasi interaktif yang ditampilkan di jejaring sosial khusus seperti YouTube atau disematkan ke situs web.

Penting bagi semua bisnis untuk memahami model bisnis dan pendapatan dari jaringan dan platform sosial utama yang saat ini sangat berpengaruh dalam membentuk pendapat orang tentang merek (brand). Menurut Chaffey55, ada 6 kategori terbagi di dalam media sosial.

1. Social networking. Jejaring sosial, penekanannya di sini adalah mendengarkan pelanggan dan berbagi konten yang menarik. Facebook dan Twitter cenderung paling penting untuk audiens konsumen sedangkan LinkedIn untuk audiens bisnis.

2. Social knowledge. Pengetahuan sosial, ini adalah jejaring sosial informasi seperti Yahoo! Answers, di mana pemasar dapat membantu audiens dengan memecahkan masalah mereka dan secara halus menunjukkan bagaimana produk tersebut telah membantu orang lain

3. Social sharing. Ini adalah situs bookmark sosial seperti Pinterest yang dapat berguna untuk memahami konten yang paling menarik dalam suatu kategori, bisa dalam bentuk gambar, video, atau link yang diberi judul dan label untuk memudahkan pengguna lain menemukannya.

4. Social news. Twitter adalah contoh yang paling popular untuk berbagi berita.

5. Social streaming. Situs sosial media yang bisa mengirim data secara terus-menerus (stream) secara real-time dan.kaya akan foto, video, dan podcast (rekaman audio atau video yang tersedia di internet) seperti YouTube.

6. Company user-generated content and community. Berbeda dari jenis lain dari kehadiran jejaring sosial yang independen dari perusahaan, ini adalah ruang sosial perusahaan yang dapat diintegrasikan ke dalam konten produk (review dan rating), komunitas dukungan pelanggan atau blog yang berisi ulasan dari pengguna (customers).

Jadi, Social Media Marketing adalah strategi kegiatan pemasaran menggunakan situssitus media sosial seperti Facebook, Twitter, Instagram, Pinterest, Youtube, dan sebagainya. Media sosial merupakan salah satu cara yang ampuh untuk mempromosikan produk barang dan jasa yang kita miliki melalui internet marketing. Caranya mudah sederhana tetapi memiliki efek yang luar biasa.

\section{Facebook dan Instagram Marketing}

Definisi Facebook Marketing yang dikutip dari Muttaqin adalah melakukan aktivitas pemasaran menggunakan semua fasilitas yang disediakan oleh Facebook dengan tujuan meningkatkan penjualan (sales) dan menjalin komunikasi yang lebih lama dan akrab dengan pelanggan (customer relationship). 


\section{Fitur Facebook for Business (Facebook untuk Bisnis)}

Selain akun personal atau profile, Facebook juga mengeluarkan Fan Page Facebook atau Halaman Facebook seperti blog yang menyediakan informasi yang beragam sesuai dengan keinginan pemiliknya, mulai dari perusahaan, pendidikan, layanan, produk fisik, artis, komunitas, dan masih banyak lainnya. Fitur ini lebih mengarah ke bidang bisnis. Tujuannya untuk memberikan info terbuka kepada publik, selain itu Facebook juga menyediakan segala kebutuhan untuk beriklan menggunakan Facebook Ads.

Dengan adanya Fan Page membuka kesempatan pemilik halaman terhubung dengan lebih banyak pelanggan dan bisa untuk bergabung membuat sebuah komunitas dan mengembangkannya.

Sedangkan Facebook Ads (Iklan Facebook), membantu pemilik halaman untuk menemukan orang yang tepat (target), menarik perhatian mereka, dan mendapatkan hasil. Dengan dua miliar orang menggunakan Facebook setiap bulan, menjadikan Facebook wadah yang potensial.

\section{Instagram Marketing}

Sistem sosial dalam Instagram adalah dengan menjadi pengikut (followers) akun pengguna lainnya, atau memiliki pengikut Instagram. Sehingga dengan demikian komunikasi antara sesama pengguna Instagram sendiri dapat terjalin dengan memberikan tanda suka (like) dan juga mengomentari foto-foto yang telah diunggah oleh pengguna lainnya. Menurut Atmoko, sebagai aplikasi yang diminati banyak pengguna, Instagram menjadi media sosial yang banyak sekali peluang untuk berbisnis bagi para penggunanya, bisa dimanfaatkan sebagai media komunikasi pemasaran, melalui share foto-foto produk, dan tentunya memiliki banyak followers. Instagram memudahkan konsumen untuk melihat produk yang dijual dan dapat langsung memberi komentar di bawah foto yang diminati.

Menurut pendapat ahli Atmoko dalam bukunya Instagram Handbook yang menyatakan indikator dari sebuah media sosial yaitu:

1. Hashtag. Suatu label (tag) berupa kata yang diberikan awalan simbol tanda \#. Fitur pagar (tanda pagar) ini penting karena sangat memudahkan pengguna untuk. Menemukan fotofoto yang tersebar di Instagram dengan label tertentu.

2. Lokasi (Geotag). Smartphone telah dilengkapi fitur geotag yang berguna untuk mengetahui lokasi tempat pengambilan gambar.

3. Follow. Suatu sistem dengan menjadi mengikuti suatu akun pengguna lainnya, atau memiliki pengikut Instagram.

4. Share. Foto atau video dari Instagram dapat dibagi melalui jejaring sosial lainnya.

5. Like. Simbol love, digunakan sebagai penanda bahwa pengguna yang lain menyukai foto yang telah diunggah oleh pengguna lain.

6. Comment atau komentar. Bagian dari interaksi dalam Instagram memberi komentar berupa saran, pujian, atau kritikan.

7. Mention. Menyinggung pengguna lainnya di dalam judul foto (caption) dan juga pada komentar foto, bertujuan untuk berkomunikasi dengan pengguna yang disinggung. 


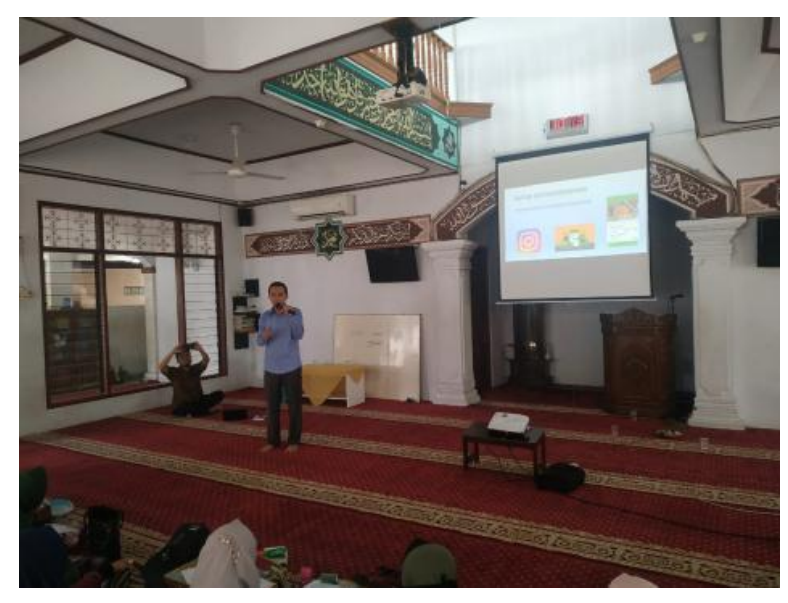

Gambar 1.

Materi Optimalisasi Instagram

Instagram sebagai media sosial berbagi foto memiliki dasar-dasar dalam penggunaanya. Menurut Landsverk yang dikutip dari Utari62 fitur penggunaan Instagram meliputi Feed. Pada fitur ini pengguna dapat melihat postingan yang diunggah teman yang sudah diikuti. Popular "tab". Digunakan pengguna untuk melihat foto yang diunggah pengguna lain. Foto atau video yang masuk ke dalam halaman populer, merupakan tempat kumpulan dari fotofoto yang paling banyak disukai setiap waktunya. Jika ingin melihat suatu hal yang lebih spesifik, bisa menuliskan pada kolom pencarian username dan hashtag. News and Updates.

Dengan Instagram memungkinkan berinteraksi dengan teman yang diikuti melalui foto atau video yang diunggah dengan like atau comment dan memunculkan notifikasi pada akun kita yang memberikan informasi pengguna Instagram lain. Like, Comment, Bookmark. Like atau comment pada Instagram adalah sebuah apresisasi dan penghargaan tersendiri bagi pengguna Instagram. Jika pengguna tertarik pada suatu unggahan, maka kita bisa memberikan like pada foto tersebut dengan memberikan. double tap ditandai dengan muncul simbol love pada layar dan comment jika ingin berinteraksi dengan pengguna lain.

Dalam Instagram memang tidak menyediakan fitur untuk download, namun apabila menyukai postingan tertentu dan ingin melihatnya lagi di lain waktu, fitur bookmark atau simpan. Your Profile. Profil dapat dilihat pada ikon user, di pojok kanan bawah. Pada profile tersimpan arsip-arsip foto yang pernah diunggah. Posting. Adalah sebutan ketika akan mengunggah foto. Foto yang akan diunggah dapat diberi filter bawaan dari Instagram agar terlihat menarik. Dikutip dari situs digitalmarketer.id63, di tahun 2016 Instagram mempunyai fitur tambahan yakni Instagram Stories. Fitur ini mendorong pengguna agar membuat dan membagi konten lebih banyak lagi yang tidak akan muncul di profile grid atau dalam Instagram feed.

\section{KESIMPULAN DAN SARAN}

\section{Simpulan}

Kegiatan Pengabdian Kepada Masyarakat dilaksanakan Masjid Al Awwal Jalan Mawar Raya Depok Jaya, Penerapan digital marketing sebagai startegi UMKM. Kegiatan pengabdian kepada masyarakat berjalan lancar sesuai rencana pelaksanaan kegiatan. 
Pelaksanaan kegiatan PKM mendapatkan sambutan dan apresiasi dari seluruh peserta pelatihan dan berbagai pihak yang terkait: bapak Lurah Depok Jaya. Bahkan, dari warga meminta pihak Universitas Pamulang Tangerang Selatan untuk mengadakan kegiatan ini secara berkesinambungan, tidak hanya sekali dilakukan.

Dampak atas adanya progam pengabdian masyarakat ini, Strategi komunikasi pemasaran melalui digital marketing yang dilakukan oleh pelaku usaha UKM Diah Cookies dan UKM Pawon Kue yaitu penyampaian positioning statement di setiap postingan Facebook dan Instagram serta menjalin hubungan dengan pelanggan secara fast respond (cepat tanggap) di media sosial. Strategi tersebut dapat membangun dan mempengaruhi kesadaran merek pada konsumen atau calon konsumen.

\section{Saran}

Untuk memajukan dan memasarkan produk UMKM masyarakatb Depok. Semakin dikenalnya produk UKM yang membuat produktivitas meningkat. Dengan adanya pembelian yang meningkat menciptakan dampak positif bagi masyarakat di sekitarnya untuk ikut membantu proses produksi yaitu menjadi karyawan produksi produk. Selain itu dampak dari dikenalnya produk UKM, menjadikan tempat produksi UKM Pawon Kue dan UKM Diah Cookies sering dikunjungi oleh tamu yang merupakan pelanggan atau konsumen loyalnya.

Penyuluhan dalam manajemen penerapan digital marketing sebagai strategi pemasaran UKM diharapkan dapat berkesinambungan untuk menjamin keberhasilan program ini.

\section{DAFTAR PUSTAKA}

Chaffey, D., \& E. C. F. (2019). Digital marketing. Pearson UK.

Reza, K, G. (1998). Marketing opportunities in the digital world. Internet research, 8(2), 185-194.

Stokes, R. (2011). eMarketing: The essential guide to digital marketing. Quirk eMarketing.

Solihin, D. (2020), Faktor-Faktor yang Mempengaruhi Kinerja Pemasaran Pada PT. Prima Ufuk Semesta Studi Pada Outlet Rekanan PT. Prima Ufuk Semesta di Wilayah JABODETABEK, Jurnal Semarak, Vol. 3 No.1. 